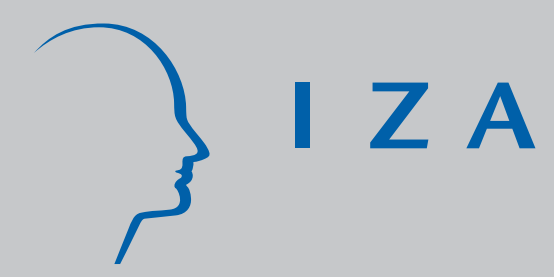

IZADP No. 2562

Corporate Skills as an Ex-Ante Incentive to R\&D Investment

Mariacristina Piva

Marco Vivarelli

J anuary 2007 


\title{
Corporate Skills as an Ex-Ante Incentive to R\&D Investment
}

\author{
Mariacristina Piva \\ Università Cattolica Piacenza \\ Marco Vivarelli \\ Università Cattolica Piacenza, CSGR Warwick, \\ Max Planck Institute of Economics Jena, and IZA
}
Discussion Paper No. 2562
January 2007

\author{
IZA \\ P.O. Box 7240 \\ 53072 Bonn \\ Germany \\ Phone: +49-228-3894-0 \\ Fax: +49-228-3894-180 \\ E-mail: iza@iza.org
}

\begin{abstract}
Any opinions expressed here are those of the author(s) and not those of the institute. Research disseminated by IZA may include views on policy, but the institute itself takes no institutional policy positions.

The Institute for the Study of Labor (IZA) in Bonn is a local and virtual international research center and a place of communication between science, politics and business. IZA is an independent nonprofit company supported by Deutsche Post World Net. The center is associated with the University of Bonn and offers a stimulating research environment through its research networks, research support, and visitors and doctoral programs. IZA engages in (i) original and internationally competitive research in all fields of labor economics, (ii) development of policy concepts, and (iii) dissemination of research results and concepts to the interested public.
\end{abstract}

IZA Discussion Papers often represent preliminary work and are circulated to encourage discussion. Citation of such a paper should account for its provisional character. A revised version may be available directly from the author. 
IZA Discussion Paper No. 2562

January 2007

\begin{abstract}

\section{Corporate Skills as an Ex-Ante Incentive to R\&D Investment}

Using a balanced panel of 215 Italian manufacturing firms over the 1995-2000 period, this paper investigates the determinants of R\&D investment at the level of the firm. While finding further support for the well-established technology-push and demand-pull hypotheses, this study also tests the role of skill endowment in increasing a firm's R\&D investment. Consistently with the related managerial and economic literature, our basic result is that current skill endowment may significantly and positively influence a firm's current R\&D decision. These microeconometric results have been obtained using a Least Squares Dummy Variable Corrected (LSDVC) estimator, a recently-proposed panel data technique particularly suitable for small samples.
\end{abstract}

JEL Classification: $\quad 031$

Keywords: $\quad$ skills and innovation, R\&D expenditures, endogenous skill bias, demand-pull, LSDVC estimator

Corresponding author:

Marco Vivarelli

Facoltà di Economia

Università Cattolica

Via Emilia Parmense 84

I-29100 Piacenza

Italy

E-mail: marco.vivarelli@unicatt.it 


\section{Introduction}

It is widely recognized that corporate skills and innovation are complementary in fostering a firm's business performance. However, most previous studies have focused either on the skillbiased impact of innovation or on the joint impact of innovation and skills in determining above- average productivity and /or profitability in a firm’s performance.

The novelty of this study is the attempt to investigate the missing link in the triangle skillsinnovation-performance, i.e. the possible role of current skills in determining corporate $R \& D$ investment. Hence, the basic research question of this paper can be summarized as follows: is a firm's larger ex ante skill endowment a good predictor of higher R\&D investment? In other words, the hypothesis put forward in the next sections is that a better workforce skill endowment may increase the "ex-ante" expected profitability of R\&D investment and so increase a firm's R\&D expenditures.

Although specific literature explicitly discussing the possibility that upskilling can induce R\&D investment does not exist (at least to the best of our knowledge); there is a considerable number of managerial and economic studies that propose arguments which indirectly support the hypothesis investigated in this study. In the second section of this paper, we will try to examine these different strands of literature critically.

Section 3 will describe the microdata used in this study and will introduce the relatively new least-squared-dummy-variable-corrected (LSDVC) methodology used in the econometric estimates, the results of which will be discussed in the following Section 4. Finally, Section 5 will propose some conclusions.

\section{Previous literature}

What are the arguments which support the view that upskilling may imply a higher level of R\&D investment? In our view, there are different strands of literature that can be recalled to sustain that higher skills may increase the expected value of $R \& D$ expenditure. They can be grouped into two broad categories. 


\section{A) Individual incentives, organizational change and absorptive capacity}

At the level of the single firm, upskilling is crucial in enhancing innovation in terms of individual creativity, organizational change and acquisition of external knowledge. Let us discuss these three dimensions separately.

At the level of the individual worker, skilled employees who feel confident in performing a range of proactive tasks requiring autonomous initiative are surely more likely to be successful in exploring and/or exploiting innovative ideas (Parker, 1998; Axtell et al. 2000; West, 2002). By the same token, Morrison and Phelps (1999) have shown that skilled workers who "feel responsibility" are more likely to successfully take charge of workplace change and innovation. Conversely, unskilled and passive workers are unlikely to come up with new ideas, since they feel that it someone else's job to do so while they are unable to make connections between divergent stimuli (see Guthrie, 2001). Finally, skilled people manage to deal with complexity, and job complexity positively interacts with creativity, innovation and suggestion making as regards how to improve processes and products and to meet identified gaps (see Scott and Bruce, 1994; Oldham and Cummings, 1996; Song, Almeida and Wu, 2003).

However, skills enhance both individual and collective (organisational) innovativeness. Nahapiet and Ghoshal (1998) have shown that knowledge is not just an individual attribute but has a collective, tacit dimension (see also Damanpour, 1991; Gittell, 2000). In this framework, some recent literature shows how team work and innovation are closely related. Parker et al. (1997) found that innovation is more likely when team members have a wide range of responsibilities and have more control over the execution of their tasks; Anderson and West (1998) showed that organisational innovation increases when members feel that new ideas are encouraged and expected and when they feel skilled enough to participate in decision-making and voice their suggestions openly; West et al. (2004) - using an input/process/output model - singled out twelve managerial steps which should enable organization's teams to become innovative.

On the whole, adequate skills emerge as a "conditio sine qua non” for enhancing individual and organisational innovativeness. Moreover, technological and organizational changes often 
go hand in hand. Indeed, a recent strand of literature has emphasised that innovation and organisational change are complementary to each other, and that they often generate superadditive effects on firm's performance, measured in terms of either productivity or profitability (see Pavitt et al., 1989; Milgrom and Roberts, 1990 and 1995; Black and Lynch, 2001; Piva et al., 2005 and 2006). Conversely, the mismatch between technological change and organisational inertia may generate an adverse impact on a firm's performance (the socalled “Solow paradox”; see Brynjolfsson et al., 1997; Brynjolfsson and Hitt, 2000).

However, at the corporate level, skills are the third component of a "triangle" able to sustain better business performance and higher returns (see Hitt and Brynjolfsson, 1997; Siegel et al., 1997; Caroli, 2001; Bresnahan et al., 2002). In other words, skills are even more valuable when a firm is affected by both technological and organisational change, since the lack of updated and flexible skills may become an important bottleneck for the firm's innovation management strategy ${ }^{1}$. In this context, a firm which invests in R\&D and also values the complementary role of organisational change would be particularly sensitive to its own skill endowment.

Of course, human resource management (HRM) can actively influence a firm's human capital in order to update skills and enhance a firm's potential in terms of technological and organisational change (see Shipton et al., 2006). Indeed, HRM promotes product and process innovation to the extent that people and the networks to which they belong are enabled to create, transfer and institutionalize their firm's internal knowledge (see Wilson, 1992; Senior, 1997; Paton and McCalman, 2000). However, the rapidly-increasing literature linking HRM and innovation can actually be seen as further confirmation of the role of skills in fostering innovation.

For instance, Michie and Sheehan (1999) - using evidence from the UK's 1990 Workplace Industrial Relations Survey - show that "high road HRM practices" are positively correlated to

${ }^{1}$ Uncertainty and fixed costs related to technological and organizational change create incentives for firms characterised by an unskilled workforce to resist innovation. Conversely, the probability of being an early adopter of a profitable innovation is positively correlated with the availability of human capital (see Wozniak, 1987). 
investment in R\&D and new technologies such as new machinery and equipment. Laursen and Foss (2003) - on the basis of data from 1,900 Danish firms - come to a similar conclusion showing that the joint adoption of interdisciplinary workgroups, quality circles, job rotation, delegation, and internal and external training significantly increases the likelihood of introducing an innovative product/service. Shipton et al. (2005) - using data from 111 UK companies - conclude that the sophistication and extensiveness of $H R M^{2}$ positively influences process and product innovation after checking for firms' size and profitability. However, Searle and Ball (2003) - surveying 300 out of the top 500 UK companies - show that organizations use a limited range of HRM tools (recruitment, training and performance management) to identify and support innovation.

Thus, appropriate HRM strategies increase the likelihood of successful innovation. The other side of the coin is simply that an adequate ex-ante endowment of skills can increase the expected value of innovation because expensive HRM policies become much more effective ${ }^{3}$ when the recipient workforce is adequately skilled. Hence, the literature linking HRM and innovation indirectly supports the view that upskilling can increase the expected value of $R \& D$ investment and so induce higher $R \& D$ expenditures.

Finally, it is well known that firms invest in $\mathrm{R} \& \mathrm{D}$ not only to produce innovation, but also in order to create internal capacity (see Cohen and Levinthal, 1989) able to absorb external knowledge coming from other firms and scientific institutions like universities and public labs. In other words, firms that conduct their own R\&D are better able to identify, assimilate and exploit externally available knowledge. However, “an organisation’s absorptive capacity will depend on the absorptive capacities of its individual members” (Cohen and Levinthal, 1990, p. 131). In this framework, skilled labour is a necessary complement to R\&D activities in reinforcing the absorptive capacity of a given organisation.

For instance, Leiponen (2005) underlines the fact that skills are an important component of absorptive capacity, being complementary to internal $R \& D$, collaborative $R \& D$ joint ventures and a firm's implementation of external knowledge; her results clearly indicate that internal

\footnotetext{
${ }^{2}$ Rated on a scale from 1 to 5 .

${ }^{3}$ Or even not necessary if the firm's workforce is already skilled enough to effectively implement the expected innovation.
} 
skills (proxied by educational levels) complement external collaboration strategies in positively affecting a firm's operating profit margin. This is an additional channel which renders R\&D investment ex-ante more profitable for those firms which are well endowed with skilled labour.

To conclude, previous literature suggests that the availability of skills is a crucial factor in enhancing creativity by the single workers, fostering teams' innovativeness and organizational change and increasing capability to absorb external knowledge. For all these dimensions, in most cases the generation of creative ideas and their implementation (see West, 2002) fall outside the narrow remit of technical specialists in R\&D departments, involving all of a firm's functions and the entire workforce. In other words, all members of a given organization should have the necessary skills and motivation to support technological and organisational change. In this context, firms which are already well endowed with adequate skills should be aware of their advantage in producing, adopting and implementing innovation and therefore should be more inclined to invest in R\&D.

\section{B) Endogenous skill bias and complementarity}

Since the '90s, economists have put forward the idea that Information and Communication Technologies (ICT) were conducive of labour upskilling. Evidence supporting the skill-biased technological change (SBTC) hypothesis was first provided with regard to the US (Berman et al., 1994; Doms et al., 1997), then to the UK (Machin, 1996; Haskel and Heden, 1999), and continental Europe (Machin and Van Reenen, 1998).

Hence, the general consensus was that computerisation and ICT have led to an increase in the demand for skilled labour (generally proxied by non-productive workers, i.e. white-collars), and in its relative wage. Yet - while the dominant approach has seen skill bias as a consequence of an exogenous technological change - some authors (Acemoglu, 1996 and 1998; Kiley, 1999; Funk and Vogel, 2004) have put forward the idea that "endogenous skillbias” may in fact have induced a dominant SBTC trajectory. In such a view, which is basically macroeconomic and falls within the endogenous growth theory, it is the significant increase in the excess supply of college-educated workers in western economies during the second half of 
the XX century which has induced SBTC. In other words, the attractiveness of investing in SBTC would seem to be related to the supply of the factor which complements that technology; in particular, a large number of skilled workers would raise the incentive to invest in that technology which is intensive in the production factor having become more abundant and cheaper, i.e. skilled labour.

Moving from the macro to the microeconomic scenario, a firm-based hypothesis can be proposed. When investing in $R \& D$, a firm's management can well predict that the likely final outcome, although uncertain and delayed, of the R\&D decision will be a SBTC reinforcing the capital-skill complementarity (Griliches, 1969; Goldin and Katz, 1998). This means that the firm's present skill endowment increases the expected profitability from innovation and so the amount of current R\&D expenditure. Analytically, this means that there is a profit function characterised by supermodularity in innovation and skills ${ }^{4}$. The fact that "the whole is more than the sum of its parts" makes the more highly skill-endowed firm more inclined to invest in $\mathrm{R} \& \mathrm{D}$.

For instance, Dunne and Troske (2005), using data from US manufacturing plants, found that the likelihood of adopting a Computer Aided Design (CAD) machine was highly correlated with the proportion of skilled labour within the plant (p.2); by the same token, plants with a greater share of investment in computing equipment in 1992 experienced skill upgrading in the period 1977-1992 (p.7).

Conversely, Mohnen and Röller (2005) found that the lack of skills was the second single most important obstacle to innovation in a wide range of industries in four European countries (the first being financial constraints, ibidem, table 2, p. 1443). Consistent results came from the third Community Innovation Survey (CIS-3): finding or mobilising human resources ranks first in a list of six factors hampering innovation in Europe between 1998 and 2000 (see CRIC, 2005, table 4.3, p.47) ${ }^{5}$.

\footnotetext{
${ }^{4}$ In a standard framework, complementarity between innovation and skills means that the marginal expected return on innovation (in this case $R \& D$ expenditures) is increasing with the level of skills internal to the firm, or more formally that the cross-partial derivatives of the expected profitability function are positive (see Topkis, 1998).

5 On the macroeconomic side, Redding (1996) provides a theoretical rationalisation for Finegold and Soskice's (1988) argument that it is possible for a country to be trapped in a
} 
Moreover, skilled labour has been found to be a direct complement to R\&D activities: in the UK 2001 innovation survey, 88\% of firms that were engaged in R\&D on a continuous basis employed graduates, while this percentage dropped to $57 \%$ for the no-R\&D firms (see CRIC, 2005; table 4.5, p.64).

On the whole, firms that possess high skills should perceive R\&D investment as being more profitable, while initially low-skilled firms should be less likely to recognise profitable R\&D investment opportunities (see Leiponen, 2000). Going a step further, skill endowment may influence $R \& D$ decisions not only because of technological complementarity, but also through its effect on input prices. In fact - following the "induced bias" theory (see Hicks, 1932; Vivarelli, 1995, chap. 2) - a large ex-ante endowment of skilled workers may act as an incentive to invest in those $\mathrm{R} \& \mathrm{D}$ directions which are conducive to skill-intensive innovation. In other words, those firms which are already well-endowed with the proper skills will be less reluctant to invest in $R \& D$ and will not be afraid to incur any skill shortage or rising wages, once R\&D has generated skill-biased innovation.

For instance, using UK data on the relative wages of the relevant occupational categories and on skilled labour shortages, Nickell and Nicolitsas (1997) found that a permanent $10 \%$ increase in the number of companies reporting skilled labour shortages in the industry to which a firm belongs would lead to a permanent $10 \%$ reduction in the industry's fixed capital investment and a temporary $4 \%$ reduction in its $R \& D$ expenditure. Vice versa, a large internal endowment of skills should facilitate R\&D expenditures at the firm level.

To conclude, the economics literature ${ }^{6}$ provides theoretical and empirical arguments supporting the view that an adequate skill endowment implies complementarities and price effects which make the expected returns on $R \& D$ investment more valuable.

"low skills" equilibrium, characterized by both an unskilled workforce and a poor innovation rate.

${ }^{6}$ The discussion in Sections 2A and 2B reveals that - although often based on different methodologies - the economics and management literatures tend to converge in highlighting the role of skills in making $R \& D$ expenditures more valuable. 


\section{Econometric methodology}

Traditionally, $R \& D$ investment is related to the evolution of demand and to the technological context in terms of path-dependence, opportunity and appropriability conditions.

As far as demand is concerned, we will check for the so called "demand pull" hypothesis (see Schmookler, 1966; Scherer, 1982; Brouwer and Kleinknecht, 1999; Kleinknecht and Verspagen, 1990; Freeman, 1994; Hall et al., 1999, Piva and Vivarelli, 2006 and 2007) which underlines the following aspects: 1) a positive demand evolution can increase the expected profitability from innovation; 2) an increase in market share increases the degree of innovation appropriability; and 3) a higher cash flow can alleviate possible credit constraints in financing the R\&D investment.

However, R\&D investment is characterised by strong cumulativeness (the so-called “technology-push” hypothesis). Indeed, within a firm, R\&D activities are highly localised (Atkinson and Stiglitz, 1969) and path-dependent (see Nelson and Winter, 1982; David, 1985; Rosenberg, 1982; Arthur, 1988; Dosi, 1988; Ruttan, 1997; Antonelli, 1998). These considerations open the way to a dynamic specification of the R\&D investment decision.

Finally, sectoral peculiarities in terms of different technological opportunities may be important in affecting R\&D investment (Pavitt, 1984; Malerba and Orsenigo, 1996; Breschi et al., 2000; Malerba, 2005).

Taking all these considerations into account, we can put forward a dynamic specification of the $R \& D$ decision of the type:

$$
R D_{t}=\alpha+\beta R D_{t-1}+\gamma \text { Sales }_{t}+v_{t}
$$


where the lagged dependent variable takes into account the "technology-push" hypothesis and, in particular, the path-dependent and localised nature of technological change within a firm, and the Sales regressor is a direct way to represent the “demand-pull” hypothesis".

Taking the discussion presented in Section 2 into account, the entire firm's innovation strategy may benefit from a strong skill-base, and employees' skills are expected to complement the effect of innovation on the firm's profitability. Hence, Section 2 motivates the main purpose of this paper, which is to test an augmented version of (1):

$$
R D_{t}=\alpha+\beta R D_{t-1}+\gamma \text { Sales }_{t}+\vartheta\left(\frac{W C}{B C}\right)_{t}+\kappa\left(\frac{W C}{B C}\right)_{t-1}+v_{t}
$$

where the ratio between white (WC) and blue (BC) collars is taken as a proxy of the skill endowment within a given firm ${ }^{8}$; the lagged term is inserted to control for delayed effects and to make the computing of long-term coefficients possible.

The dynamic specification (2) will be tested using a unique longitudinal database, suitable for panel data analysis. This new database is derived from questionnaire surveys collected by the Italian investment bank Mediocredito Centrale (MCC, now Capitalia) and involving representative samples of Italian manufacturing firms with no less than 11 employees. The original MCC database comes from two different questionnaire waves, each of them collecting contemporary and retrospective (previous two years) data from samples of more

\footnotetext{
${ }^{7}$ Sectoral technological opportunities can be taken into account through the insertion of twodigit sectoral dummies, see Section 4.

8 This can be considered a rather rough measure of skills. However, in contrast with case studies, cross section analyses have necessarily to rely on an aggregate measure. Another possible indicator is the percentage of college graduates within a firm's workforce; unfortunately, our dataset provides longitudinal data only for white and blue collars and not for education levels. This prevents the use of this variable in the following panel data analysis. At any rate, the two ratios are generally highly correlated; in fact, the correlation coefficients in the two years (1997 and 2000) where education data are available turn out to be 0.90 and 0.88 respectively.
} 
than four thousand firms ${ }^{9}$. In order to obtain a balanced panel dataset, we merged the two waves (1995-2000) and kept only the overlapping firms declaring continuous data on R\&D expenditure, sales and skill endowment. We ended up with a panel of 215 firms over a 6-year period.

Monetary variables are expressed at 1995 constant prices; some descriptive statistics are given in Table 1.

\section{Insert Table 1}

As a preliminary step, we split our sample in two groups according to their skill intensity (below and over the median of $\mathrm{WC} / \mathrm{BC}$ ) and we look for possible differences in the R\&D intensity (R\&D/Sales) between the two groups in 1997 and 2000 (see Figures 1 and 2).

\section{$\underline{\text { Insert Figures } 1 \text { and } 2}$}

As can be seen, those firms which are better endowed in terms of skill turn out to be more inclined to invest in $\mathrm{R} \& \mathrm{D}$; their density functions are more skewed to the right and present substantially higher mean values in the R\&D/Sales ratio (2.9\% vs $1.2 \%$ in 1997 and $2.5 \%$ vs $1.5 \%$ in 2000).

Obviously, this univariate analysis provides only tentative evidence and does not yet establish a causal link between skill endowment and $R \& D$ expenditure, since the revealed evidence may be driven by unobserved heterogeneity and be affected by the direct and crossover effects of other possible determinants of $R \& D$ investment. Therefore, we now turn to the econometric test of the following specification for firms (i) over time (t):

$$
\begin{aligned}
& R D_{i, t}=\alpha+\beta R D_{i, t-1}+\gamma \text { Sales }_{i, t}+\vartheta\left(\frac{W C}{B C}\right)_{i, t}+\kappa\left(\frac{W C}{B C}\right)_{i, t-1}+\left(\eta_{i}+\lambda_{t}+v_{i, t}\right) \\
& i=1, \ldots, N ; t=1, \ldots, T
\end{aligned}
$$

\footnotetext{
9 Although they are apparently very attractive for research purposes, these surveys are characterised by some shortcomings, the most important of which is that the sample
} 
where variables are expressed in natural logarithms, $\eta$ is the idiosyncratic individual and timeinvariant firm's fixed effect and $v$ the usual error term ${ }^{10}$. In addition, $\lambda$, the unobservable time effect, has been inserted to check for possible macroeconomic and business cycle effects $^{11}$.

The reasons for taking the lagged dependent variable into consideration as a first regressor are both interpretative (see above) and econometrical: in fact, the revealed persistence of the R\&D variable $(\rho=0.79)$ also calls for a necessary AR(1) check.

Once we have checked for lagged $R \& D$, sales are considered in order to check for the demand-pull hypothesis.

Finally, our main determinant (WC/BC) is considered in its contemporaneous and lagged impact $^{12}$. Since R\&D may be an antecedent of a skill-biased technological change, a possible endogeneity problem has to be considered. However, our dependent variable measures an initial, pre-innovation investment in $R \& D$, with $R \& D$ expenditure having an uncertain and delayed outcome in terms of subsequent SBTC. Since only subsequent successful innovation can have an impact on skill distribution, the possible reverse effect is not between current $R \& D$ expenditure and current skill endowment, but between future successful SBTC and future skill proportions ${ }^{13}$. This makes the possible insurgence of endogeneity with regard to our main regressor extremely unlikely ${ }^{14}$.

overlapping across waves is unfortunately rather small.

${ }^{10}$ Under the assumption that the disturbances are independent across firms.

${ }^{11}$ Accordingly, in the following econometric analysis, regressions will include time dummies (see Section 4).

${ }^{12}$ Of course, it would have been better to take higher degree lags of our main impact variable (WC/BC) into account; unfortunately, when dealing with short panels, a trade-off exists between the implementation of further lags and the acceptable extension of the time dimension of the used dataset.

${ }^{13}$ It is reasonable to assume that the final skill-bias effect of current R\&D expenditure will be detected well over the short time dimension of the panel used in this study.

${ }^{14}$ Consistently with this conclusion, the Arellano-Bond estimator used for initialising the adopted econometric procedure (see below) on the overall sample of 215 firms does not accept the assumption of endogeneity of WC/BC; in fact, the corresponding Sargan test rejects the null hypothesis of validity of instruments under the assumption of the endogeneity of $\mathrm{WC} / \mathrm{BC}\left(\chi^{2}=33.79 * * *\right)$. 
However, the need for considering the lagged dependent variable implies another obvious problem of endogeneity. A natural solution for first-order dynamic panel data models is to use GMM (General Method of Moments; see Anderson and Hsiao, 1981; Arellano and Bond, 1991; Arellano and Bover, 1995; Blundell and Bond, 1998). Unfortunately, this method is only efficient asymptotically and turns out not to be suitable for small samples (such as the one used in this study).

Therefore, we have implemented a rather new methodology, suitable for small panels, proposed by Kiviet (1995 and 1999), Judson and Owen (1999), Bun and Kiviet (2001 and 2003), and extended by Bruno (2005a and 2005b) to unbalanced panels. In what follows, we briefly reconsider the properties of the adopted methodology: the so-called Least Squared Dummy Variables Corrected (LSDVC) estimator.

In the case of an autoregressive panel data model, the LSDV estimator is the following:

$$
L S D V=\left(W^{\prime} A W\right)^{-1} W^{\prime} A y
$$

where $y$ is the vector of observations for the dependent variable, $W$ is the matrix of the explanatory variables including the lagged dependent variable and $A$ is the withintransformation which wipes out the individual effects. However, in the case of first-order dynamic panel data models, the LSDV estimator turns out to be not consistent and its bias has to be corrected.

In their Monte Carlo simulations, Bun and Kiviet (2003) and Bruno (2005a) consider three possible nested approximations of the LSDV bias ${ }^{15}$.

${ }^{15}$ The LSDV bias is given by: $c_{1}\left(T^{-1}\right)+c_{2}\left(N^{-1} T^{-1}\right)+c_{3}\left(N^{-1} T^{-2}\right)+O\left(N^{-2} T^{-2}\right)$ (see Bun and Kiviet, 2003, p.147). In particular, with an increasing level of accuracy, it is possible to identify different levels of bias: $B_{1}=c_{1}\left(T^{-1}\right) ; B_{2}=B_{1}+c_{2}\left(N^{-1} T^{-1}\right) ; B_{3}=B_{2}+c_{3}\left(N^{-1} T^{-2}\right)$. 
In this study we will correct for the most comprehensive and accurate one ( $\mathrm{B}_{3}$ in Bun and Kiviet (2003) and Bruno (2005a) notations). Therefore, in the following, the LSDV corrected estimator (LSDVC) is equal to:

$$
L S D V C=L S D V-B_{3}
$$

Again through their Monte Carlo experiments, Kiviet (1995), Judson and Owen (1999) and Bun and Kiviet (2001) have shown that the LSDVC estimator outperforms GMM estimators such as the Anderson-Hsiao and the Arellano-Bond for small samples.

However, the procedure has to be initialised by a consistent estimator to make the correction feasible, since the bias approximation depends on the unknown population parameters. In this study, we have initialised bias correction with the Arellano-Bond estimator ${ }^{16}$.

Finally, the small size of the sample poses a problem in evaluating the variability of the coefficients. Indeed, Bun and Kiviet (2001) derived the asymptotic variance of the LSDVC estimator for large N. However, the estimated asymptotic standard errors may provide poor approximations in small samples, generating possibly unreliable t-statistics; in these cases, a possible solution is to use bootstrap methods, which generally provide approximations to the sampling distributions at least as accurate as approximations based upon first-order asymptotic assumptions (see also Bruno, 2005b). Accordingly, in this study the statistical significance of the LSDVC coefficients has been tested using bootstrapped standard errors (100 iterations).

In the next section estimates are run using OLS, LSDV and LSDVC estimates. The first are affected by both fixed effects and endogeneity; the second wipe out fixed effects ${ }^{17}$; the third

16 Three possible options for this purpose are the Anderson-Hsiao, Arellano-Bond and Blundell-Bond estimators. The three alternative procedures are asymptotically equivalent. See Bruno (2005b, pp. 5 and ff.) for instructions on Stata command $x t l s d v c$.

${ }^{17}$ In our analysis we wipe out all the firms' time-invariant fixed effects that might influence a firm's incentive to engage in R\&D investment and which may explain why only some firms are innovative (see Veugelers, 1997; Cassiman and Veugelers, 2002). While this is an important stream of literature in explaining both $R \& D$ and cooperative $R \& D$ decisions in a static, cross-sectional framework (see Colombo and Garrone, 1996; Piga and Vivarelli, 2003 
also take the endogeneity of the lagged $R \& D$ variable into account. While OLS and LSDV are reported for completeness, the more reliable outcomes are those from the LSDVC estimate.

\section{Results}

Table 2 presents the OLS, LSDV and LSDVC outcomes: both OLS and LSDV estimates exhibit a satisfactory fit (see R squared and F test respectively). As discussed in the previous section, LSDVC estimates are initialised by the Arellano-Bond estimator to get accuracy of approximation of bias $\mathrm{B}_{3}$ and are characterised by bootstrapped standard errors. Estimates are checked both for time (in order to take possible aggregate and cyclical effects into account) and sectoral dummies (two-digit sectoral dummies have been included). For computational reasons, it was impossible to insert sectoral dummies into the LSDVC estimates; however, their inclusion in the OLS and LSDV estimates affects the values and the significance of the relevant coefficients only negligibly ${ }^{18}$.

\section{Insert Table 2}

As is immediately clear, estimates are affected by a strong path-dependence in R\&D expenditure; as expected, the coefficients of the lagged dependent variable are all significant to a $99 \%$ degree of confidence. This confirms the presence of cumulative technological trajectories at the level of the single firm. On the whole, the technology-push hypothesis receives further confirmation from this study.

As far as sales are concerned, they turn out to positively affect R\&D investment. In all the three estimates, the relevant coefficient is significant to a $99 \%$ level of confidence and in the LSDVC regression the related elasticity is 0.43 , meaning that doubling a firm's own demand should imply an increase in R\&D investment of about 43 per cent. These outcomes can be seen as further confirmation of the demand-pull hypothesis.

and 2004), in our dynamic analysis only innovative firms are considered and fixed effects are excluded through the LSDVC estimator.

${ }^{18}$ Results available from the authors upon request. 
Turning our attention to the main focus of this analysis, the impact of skill endowment is positive, as expected, with a degree of statistical significance ranging from 90 to 99 per cent, according to the different estimates. While remaining positive, the long-run elasticity does not turn out to be significant ${ }^{19}$. On the whole, and considering the conservative and cautious methodology adopted ${ }^{20}$, these results give support to the hypothesis that current skill endowment may significantly influence a firm's current $R \& D$ decision. As reported in the last, more reliable, estimate, an increase of 100 per cent in the white-collar/blue-collar ratio would imply an increase of 23 per cent in R\&D investment. This microeconometric evidence is consistent with the managerial and economic literature discussed in Section 2.

\section{Conclusive remarks.}

Besides finding further support for the well-established technology-push and demand-pull hypotheses, this paper has also tested the role of skill endowment in increasing a firm's R\&D investment.

Microeconometric results are not in contrast with this hypothesis and pave the way for further studies based on other samples across different sectors and different countries.

In particular, the positive and significant link between ex-ante available skills and R\&D investment suggests a new way to look at the alleged complementarity between skills and innovation. In other words, the co-evolution of the two dimensions has to be thought of not solely as a consequence of SBTC, but also in the other way round: an adequate ex-ante endowment of skills may accelerate R\&D investment and so assure innovation ex-post.

In terms of managerial implications, this means that training and $H R M$ can also be seen as a strategy to improve a firm's $R \& D$ effort and ultimately to improve its performance through innovation.

\footnotetext{
${ }^{19}$ In our context "long-run” elasticity takes into account the impact of both current and lagged WC/BC according to the formula $\frac{\vartheta+\kappa}{1-\beta}$ (long-run multiplier, see Verbeek, 2004, pp.311).
} 
In terms of economic policy implications, our results suggest that education and training policies can act as indirect subsidies of R\&D investment.

\section{References}

Acemoglu D. (1996) A Microfoundation for Social Increasing Returns in Human Capital Accumulation, Quarterly Journal of Economics, vol.111, pp.779-804.

Acemoglu, D. (1998) Why Do New Technologies Complement Skills? Directed Technical Change and Wage Inequality, Quarterly Journal of Economics, vol.113, pp.1055-90.

Anderson, T.W. and Hsiao, C. (1981) Estimation of Dynamic Models with Error Components, Journal of the American Statistical Association, vol.76, pp.598-606.

Anderson, N.R. and West, M.A. (1998) Measuring Climate for Work Group Innovation: development and Validation of the Team Climate Inventory, Journal of Organizational Behaviour, vol.19, pp.235-58.

Antonelli, C. (1998) The Dynamics of Localized Technological Changes. The Interaction between Factor Costs Inducement, Demand Pull and Schumpeterian Rivalry, Economics of Innovation and New Technology, vol.6, pp.97-120.

Arellano, M. and Bond, S. (1991) Some Tests of Specification for Panel Data: Monte Carlo Evidence and an Application to Employment Equations, Review of Economic Studies, vol.58, pp.277-97.

Arellano, M. and Bover, O. (1995) Another Look at the Instrumental Variables Estimation of Error-components Models, Journal of Econometrics, vol.68, pp.29-51.

Arthur, B.W. (1988) Competing Technologies: An Overview, in G.Dosi, C.Freeman, R.Nelson, G.Silverberg and L.Soete (eds.) Technical Change and Economic Theory, London: Pinter, pp.590-607.

Atkinson, A.B. and Stiglitz, J.E. (1969) A New View of Technological Change, Economic Journal, vol.79, pp.573-78.

Axtell, C.M., Holman, D.J., Unsworth, K.L., Wall, T.D., Waterson, P.E. and Harrington, E. (2000) Shopfloor Innovation: Facilitating the Suggestion and Implementation of Ideas, Journal of Occupational and Organisational Psychology, vol.73, pp.265-86.

Berman, E., Bound, J. and Griliches, Z. (1994) Changes in the Demand for Skilled Labor Within U.S. Manufacturing Industries: Evidence from the Annual Survey of Manufacturing, Quarterly Journal of Economics, vol.109, pp.367-97.

Black, S.E. and Lynch, L.M. (2001) How to Compete: The Impact of Workplace Practices and Information Technology on Productivity, Review of Economics and Statistics, vol.83, pp.434-45.

Blundell, R. and Bond, S. (1998) Initial Conditions and Moment Restrictions in Dynamic Panel Data Models, Journal of Econometrics, vol.87, pp.115-43.

Breschi, S., Malerba, F. and Orsenigo, L. (2000) Technological Regimes and Schumpeterian Patterns of Innovation, Economic Journal, vol.110, pp.388-410.

Bresnahan, T., Brynjolfsson, E. and Hitt, L.M. (2002) Information Technology, Workplace Organization and the Demand for Skilled Labor: Firm-level Evidence, Quarterly Journal of Economics, vol.117, pp. 339-76.

${ }^{20}$ With regard both to the sets of controls and dummies and to the adopted econometric method. 
Brouwer, E. and Kleinknecht, A. (1999) Keynes-plus? Effective Demand and Changes in Firm-level R\&D: An Empirical Note, Cambridge Journal of Economics, vol.23, pp.385-91.

Bruno, G.S.F. (2005a) Approximating the Bias of the LSDV Estimator for Dynamic Unbalanced Panel Data Models, Economics Letters, vol.87, pp.361-66.

Bruno, G.S.F. (2005b) Estimation and Inference in Dynamic Unbalanced Panel Data Models with a Small Number of Individuals, The Stata Journal, 5, pp.473-500.

Brynjolfsson, E. and Hitt, L.M. (2000) Beyond Computation: Information Technology, Organizational Transformation and Business Performance, Journal of Economic Perspectives, vol.14, pp.23-48.

Brynjolfsson, E., Renshaw, A. and Alstyne, M.V. (1997) The Matrix of Change, Sloan Management Review, vol.38, pp.22-40.

Bun, M.J.G. and Kiviet, J.F. (2001) The Accuracy of Inference in Small Samples of Dynamic Panel Data Models, Tinbergen Institute Discussion Paper TI 2001-006/4.

Bun, M.J.G. and Kiviet, J.F. (2003) On the Diminishing Returns of Higher Order Terms in Asymptotic Expansions of Bias, Economics Letters, vol.79, pp.145-52.

Caroli, E. (2001) New Technologies, Organizational Change and The Skill Bias: What Do We Know? in P.Petit and L.Soete (eds.) Technology and the Future of European Employment, Cheltenham: Elgar, pp.259-92.

Cassiman, B. and Veugelers, R. (2002) R\&D Cooperation and Spillovers, Some Empirical Evidence from Belgium, American Economic Review, vol.92 , pp.1169-84.

Cohen, W.M. and Levinthal, D.A. (1989) Innovation and Learning: the Two Faces of R\&D, Economic Journal, vol.99, pp.569-96.

Cohen, W.M. and Levinthal, D.A. (1990) Absorptive Capacity: A New Perspective on Learning and Innovation, Administrative Science Quarterly, vol.35, pp.128-52.

Colombo, M.G. and Garrone, P. (1996) Technological Cooperative Agreements and Firms' R\&D Intensity: a Note on Causality Relations, Research Policy, vol.25, pp.923-32.

CRIC (2005) A Literature Review on Skills and Innovation. How does Successful Innovation Impact on the Demand for Skills and How Do Skills Drive Innovation?, CRIC report for the Department of Trade and Industry, Centre for Research on Innovation and Competition, University of Manchester: Manchester.

Damanpour, F. (1991) Organizational Innovation: A Meta-analysis of Effects of Determinants and Moderators, Academy of Management Journal, vol.34, pp.555-90.

David, P. (1985) Clio and the Economics of QWERTY, American Economic Review Proceedings, vol.75, pp.332-37.

Doms, M., Dunne, T. and Troske, K. (1997) Workers, Wages and Technology, Quarterly Journal of Economics, vol.112, pp.253-90.

Dosi G. (1988) Sources, Procedures and Microeconomic Effects of Innovation, Journal of Economic Literature, vol.26, pp.1120-71.

Dunne, T. and Troske, K. (2005) Technology Adoption And The Skill Mix of Us Manufacturing Plants, Scottish Journal of Political Economy, vol.52, pp.387-405.

Finegold, D. and Soskice, D. (1988) The Failure of Training in Britain: Analysis and Prescription, Oxford Review of Economic Policy, vol.4, pp.21-51.

Freeman, C. (1994) The Economics of Technical Change, Cambridge Journal of Economics, vol.18, pp.463-514.

Funk, P. and Vogel, T. (2004) Endogenous Skill Bias, Journal of Economic Dynamics and Control, vol.28, pp.2155-93.

Gittel, J.H. (2000) Organizing Work to Support Relational Co-ordination, International Journal of Human Resource Management, vol.11, pp.517-39. 
Goldin, C. and Katz, L.F. (1998) The Origins of Technology-skill Complementarity, Quarterly Journal of Economics, vol.113, pp. 693-732.

Griliches, Z. (1969) Capital-skill Complementarity, Review of Economics and Statistics, vol.51, pp.465-68.

Guthrie, J.P. (2001) High-involvement Work Practices, turnover, and Productivity: Evidence from New Zealand, Academy of Management Journal, vol.44, pp.180-90.

Hall, B., Mairesse, J., Branstetter, L. and Crépon, B. (1999) Does Cash Flow Cause Investment and R\&D? An Exploration using Panel Data for French, Japanese, and United States Scientific Firms, in D.Audretsch and R.Thurik (eds.) Innovation, Industry Evolution and Employment, Cambridge: Cambridge University Press, pp. 129-56.

Haskel, J.E. and Heden, Y. (1999) Computers and the Demand for Skilled Labour: Industry and Establishment-level Panel Evidence for the UK, Economic Journal, vol.109, pp.C68-C79.

Hicks, J.R. (1932) The Theory of Wages, London: Macmillan.

Hitt, L. and Brynjolfsson, E. (1997) Information Technology and Internal Firm Organization: An Exploratory Analysis, Journal of Management Information Systems, vol.14, pp.81101.

Kiley M.T. (1999) The Supply of Skilled Labour and Skill-biased Technological Progress, Economic Journal, vol.109, pp.708-24.

Kiviet, J.F. (1995) On Bias, Inconsistency, and Efficiency of Various Estimators in Dynamic Panel Data Models, Journal of Econometrics, vol.68, pp.53-78.

Kiviet, J.F. (1999) Expectation of Expansions for Estimators in a Dynamic Panel Data Model; Some Results for Weakly Exogenous Regressors, in C.Hsiao, K.Lahiri, L.F.Lee and M.H.Pesaran (eds.) Analysis of Panel Data and Limited Dependent Variables, Cambridge: Cambridge University Press, pp.199-225.

Kleinknecht, A. and Verspagen, B. (1990) Demand and Innovation: Schmookler Reexamined, Research Policy, vol.19, pp.387-94.

Judson, R.A. and Owen, A.L. (1999) Estimating Dynamic Panel Data Models: A Guide for Macroeconomists, Economics Letters, vol.65, pp.9-15.

Laursen, K. and Foss, N. (2003) New Human Resource Management Practices, Complementarities and the Impact in Innovation Performance, Cambridge Journal of Economics, vol. 27, pp.243-263.

Leiponen, A. (2000) Competencies, Innovation and Profitability of Firms, Economics of Innovation and New Technology, vol.9, pp.1-24.

Leiponen, A. (2005) Skills and Innovation, International Journal of Industrial Organization, vol.23, pp.303-23.

Machin, S. (1996) Changes in the Relative Demand for Skills in the UK Labor Market, in A.Booth and D.Snower (eds.) Acquiring Skills: Market Failures, Their Symptoms and Policy Responses, Cambridge: Cambridge University Press, pp.129-46.

Machin, S. and Van Reenen, J. (1998) Technology and Changes in the Skill Structure: Evidence from Seven OECD Countries, Quarterly Journal of Economics, vol.113, pp.1215-44.

Malerba, F. (2005) Sectoral Systems of Innovation: A Framework for Linking Innovation to the Knowledge Base, Structure and Dynamics of Sectors, Economics of Innovation and New Technology, vol.14, pp.63-82.

Malerba, F. and Orsenigo, L. (1996) Schumpeterian Patterns of Innovation, Cambridge Journal of Economics, vol.19, pp.47-65. 
Michie, J. and Sheehan, M. (1999) HRM Practices, R\&D Expenditure and Innovative Investment: Evidence from the UK’s 1990 Workplace Industrial Relations Survey (WIRS), Industrial and Corporate Change, vol.8, pp.211-38.

Milgrom, P. and Roberts, J. (1990) The Economics of Modern Manufacturing: Technology, Strategy, and Organization, American Economic Review, vol.80, pp.511-28.

Milgrom, P. and Roberts, J. (1995) Complementarities and Firms: Strategy, Structure and Organisational Change in Manufacturing, Journal of Accounting and Economics, vol.19, pp.179-208.

Mohen, P. and Röller, L.-H. (2005) Complementarities in Innovation Policy, European Economic Review, vol.49, pp.1431-50.

Morrison, E.W. and Phelps, C.C. (1999) Taking Charge at Work: Extrarole Efforts to Initiate Workplace Change, Academy of Management Journal, vol.42, pp.403-19.

Nahapiet, J. and Ghoshal, S. (1998) Social Capital, Intellectual Capital and Organizational Advantage, Academy of Management Review, vol.23, pp.242-66.

Nelson, R.R. and Winter, S.G. (1982) An Evolutionary Theory of Economic Change, Cambridge (Mass.): Balknap Press Harvard University Press.

Nickell, S. and Nicolitsas, D. (1997) Human Capital Investment and Innovation: What Are the Connections?, paper CEPDP0370, London: Centre for Economic Performance.

Oldham, G.R. and Cummings, A. (1996) Employee Creativity: Personal and Contextual Factors At Work, Academy of Management Journal, vol.39, pp.607-34.

Parker, S.K. (1998) Enhancing Role Breadth Self-efficiency: The Role of Job Enrichment and Other Organizational Intervention, Journal of Applied Psychology, vol.83, pp.835-52.

Parker, S.K, Wall, T.D. and Jackson P.R. (1997) “That's Not My Job”: Developing Flexible Employee Work Orientations, Academy of Management Journal, vol.40, pp.899-929.

Paton, R.A. and McCalman, J. (2000) Change Management. A Guide to Effective Implementation ( $2^{\text {nd }}$ ed.), Sage: Thousand Oaks.

Pavitt, K. (1984) Sectoral Patterns of Technical Change: Towards a Taxonomy and a Theory, Research Policy, vol.3, pp.343-73.

Pavitt, K., Robson, M. and Townsend, J. (1989) Technological Accumulation, Diversification and Organization in UK Companies, 1945-83, Management Science, vol.35, pp.81-99.

Piga, C.A. and Vivarelli, M. (2003) Sample Selection in Estimating the Determinants of Cooperative R\&D, Applied Economics Letters, vol.10, pp.243-46.

Piga, C.A. and Vivarelli, M. (2004) Internal and External R\&D: A Sample Selection Approach, Oxford Bulletin of Economics and Statistics, vol.66, pp.457-82.

Piva, M., Santarelli, E. and Vivarelli, M. (2005) The Skill Bias Effect of Technological and Organisational Change: Evidence and Policy Implications, Research Policy, vol.34, pp.141-57.

Piva, M., Santarelli, E. and Vivarelli, M. (2006) Technological and Organizational Changes as Determinants of the Skill Bias: Evidence from the Italian Machinery Industry, Managerial and Decision Economics, vol.27, pp.63-73.

Piva, M. and Vivarelli, M. (2006) Is Demand-Pulled Innovation Equally Important in Different Groups of Firms?, IZA Discussion Paper no. 1982, Bonn: IZA.

Piva, M. and Vivarelli, M. (2007) Demand-Pulled Innovation under Liquidity Constraints, Applied Economics Letters, forthcoming.

Redding, S. (1996) The Low-skill, Low-quality Trap: Strategic Complementarities between Human Capital and R\&D, Economic Journal, vol.106, pp.458-70.

Rosenberg, N. (1982) Inside the Black Box: Technology and Economics, Cambridge: Cambridge University Press. 
Ruttan, V.W. (1997) Induced Innovation, Evolutionary Theory and Path Dependence: Sources of Technical Change, Economic Journal, vol.107, pp.1520-29.

Scherer, F.M. (1982) Demand-pull and Technological Invention: Schmookler Revisited, Journal of Industrial Economics, vol.30, pp.225-37.

Schmookler, J. (1966) Invention and Economic Growth, Cambridge (Mass.): Harvard University Press.

Scott, S.G. and Bruce, R.A. (1994) Determinants of Innovative Behaviour: A Path Model of Individual Innovation in the Workplace, Academy of Management Journal, vol.37, pp.580-607.

Searle, R.H. and Ball, K.S. (2003) Supporting Innovation through HR Policy: Evidence from the UK, Creativity and Innovation Management, vol.12, pp.50-62.

Senior, B. (1997) Organizational Change, London: Pitman.

Shipton, H., Fay, D. West, M., Patterson, M. and Birdi, K. (2005) Managing People in Promote Innovation, Creativity and Innovation Management, vol.14, pp.118-28.

Shipton, H., West, M., Dawson, J., Birdi, K. and Patterson, M. (2006) Human Resource Management as a Predictor of Innovation, Human Resource Management Journal, vol.16, pp.3-27.

Siegel, D.S., Waldman, D. and Youngdahl, D.W. (1997) The Adoption of Advanced Manufacturing Technologies: Human Resource Management Implications, IEEE Transactions on Engineering Management, vol.44, pp.288-98.

Song, J., Almeida, P. and Wu, G. (2003) Learning-by-hiring: When Is Mobility More Likely to Facilitate Interfirm Knowledge Transfer?, Management Science, vol.49, pp.351-65.

Topkis, D.M. (1998) Supermodularity and Complementarity, Princeton: Princeton University Press.

Verbeek, M. (2004) A Guide to modern Econometrics, Chichester: Wiley, 2nd edition.

Veugelers, R. (1997) Internal R\&D Expenditures and External Technology Sourcing, Research Policy, vol.26, pp.305-15.

Vivarelli, M. (1995), The Economics of Technology and Employment: Theory and Empirical Evidence, Cheltenham: Elgar, reprinted 1997.

West, M. (2002) Sparkling Fountains or Stagnant Ponds: An Integrative Model of Creativity and Innovation Implementation in Work Groups, Applied Psychology: An International Review, vol.51, pp.355-87.

West, M., Hirst, G., Richter, A. and Shipton, H. (2004) Twelve Steps to Heaven: Successfully Managing Change through Developing Innovative Teams, Organizational Journal of Work and Organizational Psychology, vol.13, pp. 269-99.

Wilson, D.C. (1992) A Strategy for Change, London: Routledge.

Wozniak, G.D. (1987) Human Capital, Information, and the Early Adoption of New Technology, The Journal of Human Resources, vol.22, pp.101-12. 
Table 1. Descriptive statistics (monetary values at 1995 Italian lire, in millions)

\begin{tabular}{|l|c|c|c|}
\hline & $\begin{array}{c}\text { Mean } \\
\mathbf{( 1 9 9 5 )}\end{array}$ & Std. dev. & Average growth rate (1995-2000) \\
\hline Sales & 26568.34 & 56124.66 & $3.40 \%$ \\
\hline R\&D & 465.4285 & 1826.381 & $5.14 \%$ \\
\hline Employees & 168 & 344.236 & $1.06 \%$ \\
\hline White Collars / Blue Collars & 0.79 & 1.057 & $2.38 \%$ \\
\hline
\end{tabular}


Table 2: Dependent variable: $\log (\mathrm{R} \& D)$

\begin{tabular}{llll} 
& $(1)$ & $(2)$ & $(3)$ \\
& OLS & LSDV & LSDVC \\
\hline Constant & $-1.53^{* * *}$ & & \\
& $(3.22)$ & & $0.60^{* * *}$ \\
$\log (\mathrm{R} \& \mathrm{D}-1)$ & $0.62^{* * *}$ & $0.35^{* * *}$ & $(14.01)$ \\
& $(28.44)$ & $(11.82)$ & $0.43^{* * *}$ \\
$\log ($ Sales $)$ & $0.33^{* * *}$ & $0.56^{* * *}$ & $(3.23)$ \\
& $(10.74)$ & $(4.62)$ & $0.23^{* *}$ \\
$\log (\mathrm{WC} / \mathrm{BC})$ & $0.34^{* * *}$ & $0.20^{*}$ & $(2.00)$ \\
$\log (\mathrm{WC} / \mathrm{BC}-1)$ & $(3.35)$ & $(1.69)$ & -0.09 \\
& $-0.17^{*}$ & -0.03 & $(0.79)$ \\
& $(1.68)$ & $(0.29)$ & \\
\hline $\mathrm{R}^{2}$ and F test & 0.72 & & 1075 \\
Observations & 1075 & $149.63^{* * *}$ & \\
& & 1075 & \\
\hline
\end{tabular}

Notes:

- t-statistics in brackets for OLS and LSDV estimates; z-statistics for LSDVC estimates (bias correction initialised by Arellano-Bond estimator and bootstrapped standard errors): * significant at $10 \%$; ** significant at $5 \%$; ** significant at $1 \%$.

- $\mathrm{R}^{2}$ is reported for OLS estimates, $\mathrm{F}$ test is reported for LSDV estimates together with its significance level.

- Time dummies are always included and not reported; sectoral dummies are included in the OLS and LSDV specifications and not reported.

- LTE is the Long-term Elasticity; z-statistics in brackets. 
Figure 1: Density of the $R \& D /$ Sales variable in 1997

(continuous line if $\mathrm{WC} / \mathrm{BC}<=.4827586$ (median value); dotted line if $\mathrm{WC} / \mathrm{BC}>.4827586$

(Mean value of $\mathrm{R} \& \mathrm{D} / \mathrm{Sales}=0.012$ if $\mathrm{WC} / \mathrm{BC}<=.4827586 ;$ Mean value of $\mathrm{R} \& \mathrm{D} / \mathrm{Sales}=0.029$ if $\mathrm{WC} / \mathrm{BC}>.4827586$ )

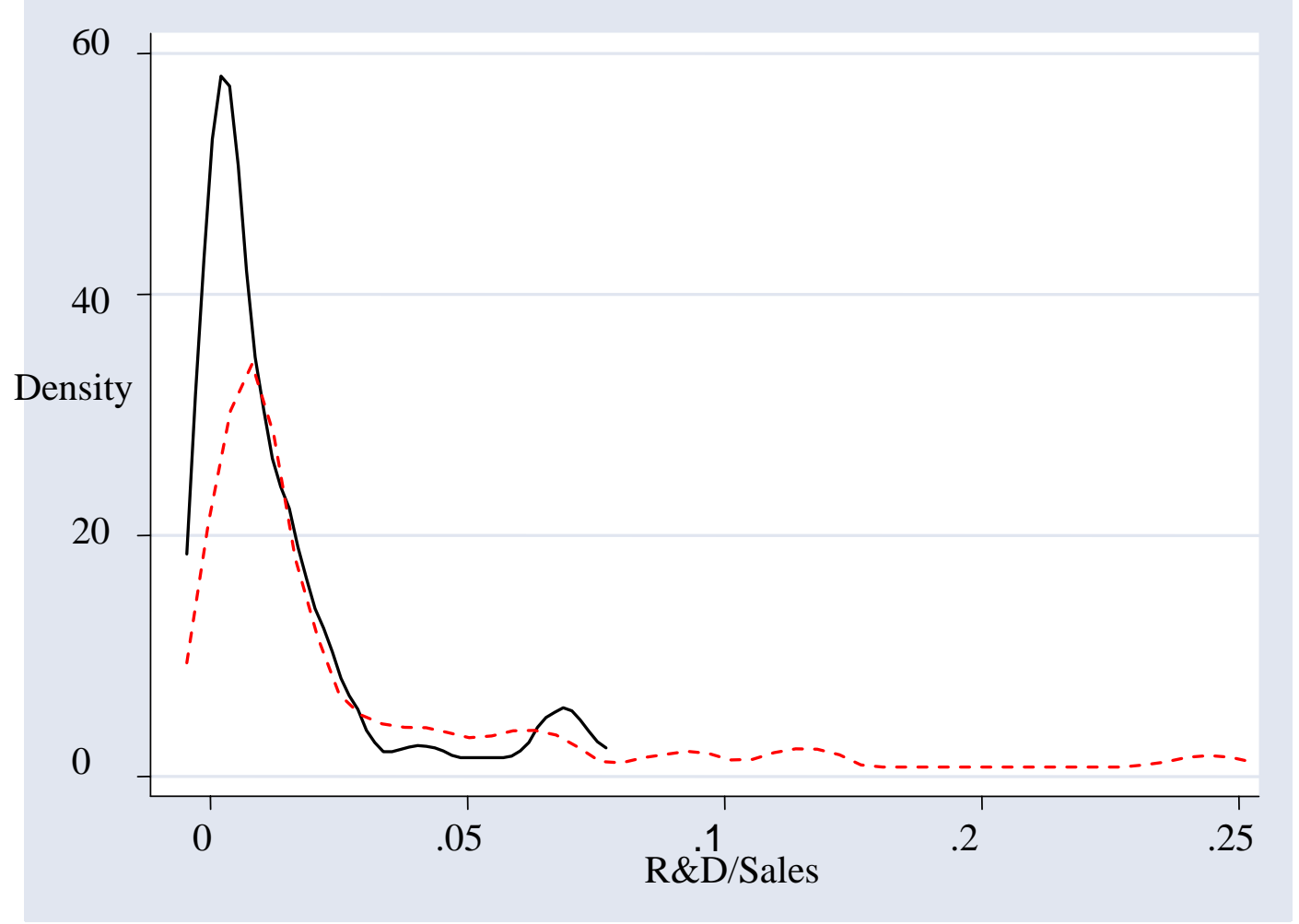


Figure 2: Density of the $R \& D /$ Sales variable in 2000

(continuous line if $\mathrm{WC} / \mathrm{BC}<=.5384616$ (median value); line if $\mathrm{WC} / \mathrm{BC}>\mathbf{. 5 3 8 4 6 1 6}$ )

(Mean value of $\mathrm{R} \& \mathrm{D} /$ Sales $=0.015$ if $\mathrm{WC} / \mathrm{BC}<=.5384616$; Mean value of $\mathrm{R} \& \mathrm{D} / \mathrm{Sales}=0.025$ if $\mathrm{WC} / \mathrm{BC}>.5384616$ )

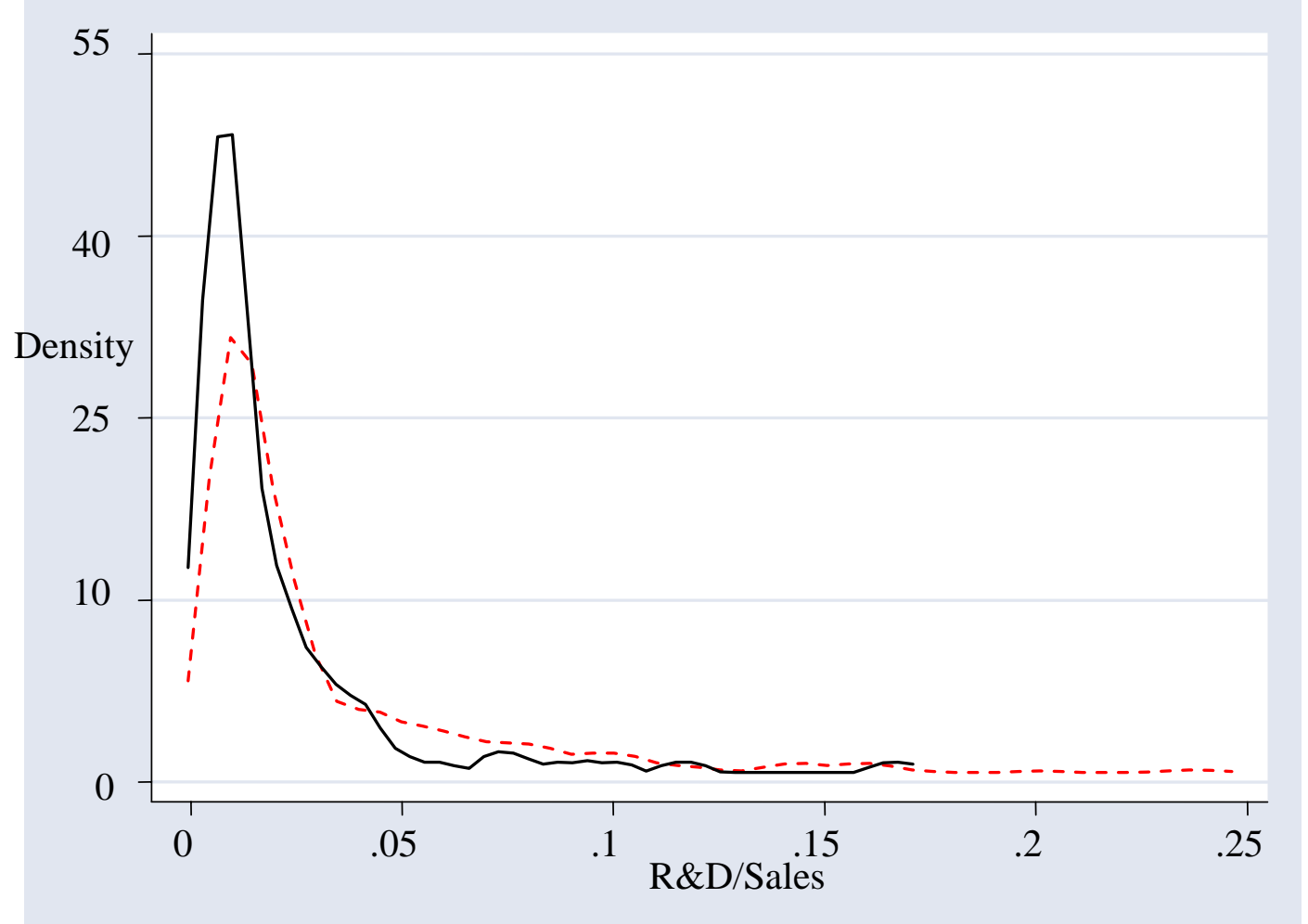

